\author{
N. A. SHCHERBINA, L. A. VYGIVSKA (Kharkiv, Ukraine)
}

\title{
IMMUNOLOGICAL PREDICTORS OF INTRAUTERINE INFECTION OF THE FETUS AND NEWBORN IN PREGNANCIES COM- PLICATED BY BACTERIAL AND VIRAL INFECTION
}

Department of Obstetrics and Gynecology № 1 (Head - prof. N. A. Shcherbina)

Kharkiv National Medical University <liudmilavygovskaya@gmail.com>

\begin{abstract}
The study involved the assessment of the state of immune system in pregnant women with bacterial and viral urogenital infection to determine the criteria for implementation of intrauterine infection (IUI) of the fetus and newborn. It implied a comparative study of the state of some parameters of immune system in 150 pregnant women with urogenital infection of mixed bacterial and viral genesis, who were in a risk group for the development of fetal IUI at the $2^{\text {nd }}-3^{\text {rd }}$ trimesters of gestation. The main group comprised $68(45.3 \%)$ women whose children, according to clinical and laboratory examination, had IUI. The comparison group included $82(54.7 \%)$ carriers of perinatally significant bacterial and viral infection who gave birth to healthy children; the control group included 50 healthy women with normal pregnancy. The study determined immunological features of pregnancy, complicated with fetal IUI. Evaluation of cytokine link in regulation of immunity in the group of pregnant women with implementation of IUI made it possible to establish a significant increase in IL-1 $\beta, I L-6, I L-10$, $T N F-\alpha$ levels in the $2^{\text {nd }}-3^{\text {rd }}$ trimesters, with a simultaneous decrease in IL-10, more expressed in the subgroup of pregnant women, who gave birth to children diagnosed with IUI, in comparison with pregnant women, whose newborns did not have clinical manifestations of the disease with a confirmed IUI. Implementation of IUI in pregnancy complicated by urogenital infection of bacterial and viral etiology at late terms of gestation is associated with an imbalance between pro- and anti-inflammatory cytokines, with the dominance of proinflammatory cytokines, the indices of which can be used as predictors for implementation of fetal IUI.
\end{abstract}

Key words: intrauterine infection of the fetus, cellular immunity, cytokines.

Introduction. Progressive incidence in intrauterine infection (IUI) of the fetusis one of the currentchallenges for obstetrics and perinatology as it is one of the main causes of perinatal morbidity and mortality. The proportion of intrauterine infections in perinatal mortality in Ukraine is almost $25 \%$, second only to fetal asphyxia and congenital anomalies [5].

The leading role in the pathogenesis of abnormal conditions developing in the perinatal period, belongs to sexually transmitted infections [11, 14], with a predominance of mixed associations of bacteria, viruses, protozoa and fungi [19, 24].

Pathogenesis of various gestational complications including intrauterine fetal infections has been recently regarded from the point of view ofclinical immunology [12, 15]. Therefore, it is relevant to study the state of systemic and local immunity in pregnant women with infectious diseases. At that, mixed bacterial and viral infection, according to [9, 13], is accompanied by more significant changes in immune homeostasis as compared tomonoinfections.

Much attention in the relationship and cooperative interaction of the immune system cells in reproduction is given to cytokines $[2,6,18]$. IL-1, IL-6, IL-10, TNF are considered to be the key markers of inflammation in the tissues and organs of the human of all the variety of pro- and anti-inflammatory cytokines [18]. However, literature dataon the cytokine status in IUI are often fragmented and highly contradictory.

The complexity of IUI diagnosis, associated with multifactorial nature of this abnormality of gestational process and nonspecific character of its clinical manifestations [17], call for the search of criteria that could predict IUI at the prenatal stage. 
The purpose of the study is to assess the state of the immune system in pregnant women with urogenital infection of bacterial and viral origin and determine the criteria for the development of intrauterine infection of the fetus and newborn.

Materials and methods. The study implied a prospective, extended, controlled examination of 150 pregnant women at high risk for bacterial and viral IUI. The patients were distributed into groups according to the findings offollow-up examination of newborns, conducted during the first day after birth. The main group consisted of 68 (45.3 \%) women, whose newbornshad intrauterine infection confirmed by clinical and laboratory examination. The comparison group $(n=82)$ included women-carriers of pathogens of perinatal bacterial and viral infections, who gave birth to healthy children. The control group amounted for 50 healthy women with normal pregnancy and their newborns who wereexaminedat the same terms as the patients of the main and comparison group. All the studies were carried out following voluntary informed consent of the pregnant women.

Examination of the women was carried out in the $2^{\text {nd }}$ and $3^{\text {rd }}$ trimesters of gestation according to medical history (premature birth, perinatal loss, purulent-septic complications of childbirth, non-developing pregnancy) and on the basis of data on complications of the current pregnancy (bacterial and viral infection, manifestations of an infectious disease of the reproductive tract); presence of foci of extragenital infection; as well as based on ultrasound IUImarkers(fetal growth retardation, disturbance of feto-placental blood flow, polyhydramnios/oligohydramnios, pyelectasia in the fetus, placentalthickness, particles in amniotic fluid, increased echogenicity of the endothelium of the internal organs).

Infectious status was determined by etiologic decoding using polymerase chain reaction (PCR), and enzyme immunoassay (EIA) for the detection of Cl.trachomatis, Ureaplasma urealiticum, Mycoplasma hominis, Mycoplasma genitalium, Nisseriagonorrheae, T. vaginalis, as well as herpes viruses (HSV-1/2,6) and cytomegalovirus (CMV).

The assessment ofcell-mediated immunity state included determination of phenotypic characteristics of populations and subpopulations of peripheral blood lymphocytes, activation markers (CD25 +, HLA-DR) and receptors for IL-1 $\beta$, IL-6, IL-10, TNF-acytokines. Lymphocyte subpopulations weredeterminedby a flow cytometer FACSCalibur (USA) (CellQuest Pro software) using standard protocols.

Serum TNF- $\alpha$ was determined by enzyme immunoassay using a set of reagents produced by Vector-Best Ltd (Novosibirsk, Russia) according to the supplied instructions, TNF- $\alpha$ concentration was shown in $\mathrm{pg} / \mathrm{ml}$. Serum IL1- $\beta$, IL-6, IL-10 content was determined by ELISA using kits manufactured by Vector-Best Ltd (Novosibirsk, Russia) according to the manufacturer's instructions. Optical density was registeredby a microplate reader and the concentration was shown in $\mathrm{pg} / \mathrm{ml}$.

Statistical processing was performed using "STATISTICA 6.1"software package (Russian version). Statistical significance of the differences between the groups was assessed using the nonparametric Mann - Whitney test.

Results and their discussion. The results of the study of cell-mediated immunity in pregnant women with bacterial and viral urogenital infections are presented in Table. 1. As can be seen from the data, IUI developmenttriggers a significant decrease in relative content of lymphocytes with CD3+, CD3+/CD4+ phenotype, accompanied by an increase in the level of lymphocytes with CD3+CD16 +/CD56+ (NK tot) phenotype.

A reduction in the relative content of T-helpers/inducers in the studied periods of gestation is an important predisposing factor for the development of immune-inflammatory reaction, and an increased level of lymphocytes with CD3+CD16/ $\mathrm{CD} 56+(\mathrm{NK}$ tot$)$ phenotype indicates an enhancement of killer activity of lymphoid cells in IUI development [4, 7].

The study did not show any significant differences between the groups in other factors of subpopulation of cell-mediated immunity.

The evaluation of cytokines under investigation showed that IUI developmentresulted in a significant increase in pro-inflammatory cytokines, namely IL-1 $\beta$, IL-6, TNF- $\alpha$. 
Table 1. Subpopulations of lymphocytes and cytokine levels in the peripheral blood of pregnant women (Me; LQ-UQ)

\begin{tabular}{l|c|c|c}
\hline \multicolumn{1}{c|}{ Indices } & $\begin{array}{c}\text { Control group } \\
(n=50)\end{array}$ & $\begin{array}{c}\text { Comparison group } \\
(n=82)\end{array}$ & $\begin{array}{c}\text { Main group } \\
(n=68)\end{array}$ \\
\hline \hline CD3+, \% & $75.5(70.5-78.4)$ & $69.2(65.8-74.4)$ & $64.2^{*}(57.5-70.3)$ \\
CD3+/CD4+, \% & $47.2(39.4-53.8)$ & $36.8(31.8-41.7)^{*}$ & $32.3^{*}(26.7-37.3)$ \\
CD3+/CD8+, \% & $24.3(23.5-32.5)$ & $23.5(18.7-30.7)$ & $20.4(16.8-30.6)$ \\
CD19+, \% & $10.5(8.5-13.5)$ & $10.0(7.7-13.6)$ & $11(7.3-14.0)$ \\
CD3+CD16+/CD56+ (NK tot) $\%$ & $5.5(4.5-6.3)$ & $8.4(6.5-12.5)$ & $12.3^{*}(5.7-14.9)$ \\
CD3+ HLA-DR, \% & $4(2.5-7.4)$ & $3.9(2.6-7.5)$ & $4.3(3.1-7.7)$ \\
IL-1 $\beta \mathrm{pg} / \mathrm{ml}$ & $6.2(0-8.5)$ & $18.4(9.6-20.3)$ & $38.8^{*}(30.2-52.7)$ \\
IL-6, pg/ml & $5.2(0-8.2)$ & $13.6(9.7-16.1)$ & $28.7^{*}(21.1-38.1)$ \\
IL-10, pg/ml & $15.5(12.5-20.5)$ & $10.8(9.6-15.5)$ & $3.2^{*}(2.5-4.9)$ \\
TNF $\alpha \mathrm{pg} / \mathrm{ml}$ & $34.6(28.1-42.4)$ & $56.8(32.2-48.9)$ & $67.6^{*}(61.1-73.2)$ \\
\hline
\end{tabular}

Note: *Significantvariationfrom the control and comparison group, $\mathrm{P}<0.05$ (Mann - Whitney test).

The study revealed almost 2 - and 7 -fold increase in IL-1 $\beta$ expression in the main group versusthe comparison group and the control, respectively. The high level of IL$1 \beta$ in the systemic circulation of the main group may indicate the activation of phagocytic immunity and cytolytic cells [23].

TNF- $\alpha$ level was almost 3 times higher than in the control group and 2 times higher than in the comparison group. TNF- $\alpha$ is an important cytokine involved in the progression of the inflammatory response by stimulating the activity of natural killer cells and cytotoxic lymphocytes, forming lymphokine-activated killer cells, thereby contributing to the development of a response to various infectious agents. Furthermore, as an inducer of apoptosis, this cytokine is able to influence the formation of the fetus, having the potential to damage the trophoblast $[9,16]$.

The level of IL-6 in IUI development was 2.5-fold higher than in the control, and 4 times higher than in the comparison group, which included women-carriers of bacterial and viral pathogens of perinatal infections, who gave birth to healthy children. High levels of this pro-inflammatory cytokine in complicated pregnancy indicates the release of immunoregulatory factors involved in the development of inflammatory reaction, namely IL- $1 \beta$ and TNF- $\alpha$, which characterizes the state of mononuclear phagocytes, determining the immunoreactivity directionvia Th1- path rather than Th2-, corresponding to normal course of gestation [21]. IL-6 expression in biological fluids is always accompanied by great variability and depends on many factors affecting intrauterine state of the fetus - threatenedmiscarriage, somatic diseases, severe preeclampsia, carrier state.

According to [15], the elevated levels of proinflammatoryTNF- $\alpha$, IL-1 $\beta$, IL-6 cytokines in the period under investigation, specificallyduring the $2^{\text {nd }}$ and $3^{\text {rd }}$ trimester, can result in an increase in prostaglandinsynthesis by amniotic membranes, contributing to the development of premature labor.

The assessment of IL-10 level revealed a 4-fold decrease in its level in the main group as compared to both the control and the comparison group. The decrease in the amount of anti-inflammatory cytokines in the development of intrauterine infection may diminish its inhibitory role in inflammation reaction, indicating an impairment of immunoregulatory mechanisms adaptation in IUI development [20, 22].

The abovementioned shows that IUI development is accompanied by a disturbance in the ratio of pro- and anti-inflammatory cytokines, a significant increase in TNF- $\alpha$, IL-1 $\beta$, IL-6 levels and a decrease inserum IL-10 in women with intrauterine fetal infection (as opposed to physiological pregnancy and pregnancy at risk for IUI, but without its development). At the same time the findings suggest a large variability in theexpression of the studied cytokines in the main group of patients.

Follow-up examination conducted during the first day after birth in the main group demonstrated that 24 newborns had intrauterine infection, the remaining 44 infants 
had no clinical manifestations of the disease having the infection confirmed. On this evidence, using a retrospective evaluation of the examination, the patients were divided into two subgroups, depending on the presence (A) or absence (B) of clinical manifestations of intrauterine fetal infection (Table 2).

Table 2. Retrospective evaluation of serum cytokines in the pregnant women of the main group

\begin{tabular}{l|c|c}
\hline \multicolumn{1}{c}{ Indices } & $\mathrm{A}(\underline{n}=24)$ & $\mathrm{B}(n=44)$ \\
\hline \hline IL-1 $\beta, \mathrm{pg} / \mathrm{ml}$ & $58.2(48.8-67.8)$ & $23.6^{*}(20.9-26.3)$ \\
$\mathrm{IL}-6, \mathrm{pg} / \mathrm{ml}$ & $29.6(11.2-40.3)$ & $9.9^{*}(3.73-14.84)$ \\
$\mathrm{TNF}-\alpha, \mathrm{pg} / \mathrm{ml}$ & $72.8(46.9-87.2)$ & $52.9^{*}(34.8-71)$ \\
$\mathrm{IL}-10, \mathrm{pg} / \mathrm{ml}$ & $1.4(0.8-2)$ & $7.6^{*}(4.8-9.8)$ \\
\hline
\end{tabular}

* Significantvariationfromthesubgroupofnewbornswithclinicalmanifestation of IUI, P < 0.001 (Mann Whitneytest).

Conclusion. As can be seen from these data, before the birth $\left(2^{\text {nd }}-3^{\text {rd }}\right.$ trimesters $)$ proinflammatory cytokines levels were significantly higher in women who gave birth to children with diagnosed intrauterine infection, in contrast to women, whose newborns had no clinical manifestations of the diseasein the presence of infection. According to $[1,3,10,13,18]$, the high level of IL-1 $\beta$ and TNF $\alpha$ may be one of the mechanisms that trigger the development of pathological reactions which contribute to the progression of complications of infection in the newborn. Increased levels of proinflammatory cytokines, conditioned by their involvement in the immune reaction of the body exposed to infection leads to inflammatory reactions, initiating IUI development.

The findings obtained in our study are consistent and fully in line with the evidence that the imbalance of pro- and anti-inflammatory cytokines is "one of the triggers of infectious agent transition into an active inflammatory process followed by the dominance of pro-inflammatory cytokines" [16]. Consequently, prognosis of IUI developmentin gestation complicated by mixed urogenital infectioncan be determinedby the immune response direction mediated by changes in the level of cytokines towards strengthening of the pro-inflammatory functions of the body and the lack of immunosuppressive (anti-inflammatory) cytokines.

$$
\text { References }
$$

1. Аврущкая В. В. Динамика продукции интерлейкинов у женщин с осложнённым течением беременности // Рос. вестн. акушера-гинеколога. 2008. - № 3. - С. 4548.

2. Ботвиньева И. А., Ренге Л. В., Зорина В. Н. и др. Уровни цитокинов в венозной и пуповинной крови у женщин с признаками внутриутробной инфекции // Мед. иммунология. - 2013. - Т. 15, № 3. - С. 277-282.

3. Бубнова Н. И., Тютюнник В. Л., Михайлова О.И. Репродуктивные потери при декомпенсированной плацентарной недостаточности, вызванной инфекцией // Акушерство и гинекология. - 2010. № 4. - C. 55-58.

4. Буданов П. В., Стрижаков А. Н., Малиновская В. В., Казарова Ю. В. Дискоординация системного воспаления при внутриутробной инфекции / / Вопр. гинекологии, акушерства и перинатологии. - 2009. T. 2, № 8. - C. 61-68.
1. Avruckaya V. V. Dinamika produkcii interlejkinov u zhenshchin s oslozhnyonnym techeniem beremennosti // Ros. vestn. akusheraginekologa. - 2008. - № 3. - S. 45-48.

2. Botvin'eva I. A., Renge L. V., Zorina V. N. i dr. Urovni citokinov v venoznoj i pupovinnoj krovi u zhenshchin s priznakami vnutriutrobnoj infekcii // Med. immunologiya. 2013. - T. 15, № 3. - S. 277-282.

3. Bubnova N.I., Tyutyunnik V.L., Mihajlova O.I. Reproduktivnye poteri pri dekompensirovannoj placentarnoj nedostatochnosti, vyzvannoj infekciej // Akusherstvo i ginekologiya. - 2010. - № 4. - S. 55-58.

4. Budanov P. V., Strizhakov A. N., Malinovskaya V. V., Kazarova Yu. V. Diskoordinaciya sistemnogo vospaleniya pri vnutriutrobnoj infekcii // Vopr. ginekologii, akusherstva i perinatologii. - 2009. - T. 2, № 8. - S. 61-68. 
5. Давыдова Ю. А. Профилактика перинатальных инфекций и их последствий у беременных // Репродуктивная эндокринология. - 2013. - Т. 11, № 3. - С. 17-35.

6. Долгих Т. И., Баринов С. В., Тирская Ю. И. и др. Внутриутробные инфекции: иммунологические и клинико-микробиологические особенности // Рос. иммунол. журн. - 2014. - Т. 8, Вып. 17, № 1. - С. 67-72.

7. Коляченко E. С., Михайлов А. В., Чеснокова Н. П. Современные представления об этиологии, факторах риска, патогенезе внутриутробного инфицирования плода. Сообщение II. Значение недостаточности иммунологических механизмов неспецифической резистентности матери и плода в патогенезе внутриутробного инфицирования плода // Успехи соврем. естествознания. - 2003. - № 11. - С. 26-30

8. Кузьмин В. Н., Арсланян К. Н., Харченко Э.И. Современный взгляд на проблему внутриутробной инфекции // Лечащий врач. - 2016. - № 3. - С. 44-46.

9. Левкович М. А., Плахотя Т. Г., Бердичевская Е. М., Цатурян Л. Д. Особенности цитокиновой регуляции при хронической плацентарной недостаточности [Электронный ресурс] // Соврем. пробл. науки и образования. - 2016. - № 4. http://www. science-education.ru.

10. Липатов И. С., Тезиков Ю. В. Прогнозирование и диагностика плацентарной недостаточности на основе маркёров эндотелиальной дисфункции, децидуализации, апоптоза и клеточной пролиферации // Саратов. науч. мед. журн. - 2011. - Т. 7 № 1. - С. 52-59.

11. Макаров О. В., Алешкин В. А., Савченко Т. Н. Инфекции в акушерстве и гинекологии. М.: МЕДпресс-информ, 2007. - 464 с.

12. Пастман Н. М., Черных Е. Р., Хонина Н. А. и др. Иммунный статус женщин группы высокого риска по преждевременному прерыванию беременности // Вопр. гинекологии, акушерства и перинатологии. 2010. - Т. 4, № 9. - С. 28-32.

13. Сидельникова В. М., Сухих Г. Т. Невынашивание беременности: Руководство для практикующих врачей. - М.: ООО «Meдицинское информационное агентство», 2010. - 536 c.

14. Стрижаков А. Н., Буданов П. В., Давъдов А. И. Инфекции, передаваемые половым путём / / Клинические лекции по акушерству и гинекологии. - В 2 т. - Т. 2. Гинекология: Учеб. пособие / Под ред. А. Н. Стрижакова, А. И. Давыдова. - М.: ОАО «Медицина», 2010. - С. 155-197.

15. Сухих Г. Т., Ванько Л. В. Иммунные факторы в этиологии и патогенезе осложнений
5. Davydova Yu. A. Profilaktika perinatal'nyh infekcij i ih posledstvij u beremennyh // Reproduktivnaya ehndokrinologiya. - 2013. T. 11, № 3. - S. 17-35.

6. Dolgih T. I., Barinov S. V., Tirskaya Yu. I. i dr. Vnutriutrobnye infekcii: immunologicheskie i kliniko-mikrobiologicheskie osobennosti // Ros. immunol. zhurn. - 2014. - T. 8, Vyp. 17, № 1. - S. 67-72.

7. Kolyachenko E. S., Mihajlov A. V., Chesnokova N. P. Sovremennye predstavleniya ob ehtiologii, faktorah riska, patogeneze vnutriutrobnogo inficirovaniya ploda. Soobshchenie II. Znachenie nedostatochnosti immunologicheskih mekhanizmov nespecificheskoj rezistentnosti materi i ploda v patogeneze vnutriutrobnogo inficirovaniya ploda // Uspekhi sovrem. estestvoznaniya. - 2003. № 11 . - S. 26-30

8. Kuz'min V. N., Arslanyan K. N., Harchenko Eh. I. Sovremennyj vzglyad na problemu vnutriutrobnoj infekcii // Lechashchij vrach. - 2016. - № 3. - S. 44-46.

9. Levkovich M. A., Plahotya T. G., Berdichevskaya E. M., Caturyan L. D. Osobennosti citokinovoj regulyacii pri hronicheskoj placentarnoj nedostatochnosti [EHlektronnyj resurs] // Sovrem. probl. nauki i obrazovaniya. - 2016. - № 4. http://www.scienceeducation.ru.

10. Lipatov I. S., Tezikov Yu. V. Prognozirovanie i diagnostika placentarnoj nedostatochnosti na osnove markyorov ehndotelial'noj disfunkcii, decidualizacii, apoptoza i kletochnoj proliferacii // Saratov. nauch. med. zhurn. 2011. - T. 7, № 1. - S. 52-59.

11. Makarov O. V., Aleshkin V. A., Savchenko T. N. Infekcii v akusherstve i ginekologii. - M.: MEDpress-inform, 2007. - 464 s.

12. Pastman N. M., Chernyh E. R., Honina N. A. i dr. Immunnyj status zhenshchin gruppy vysokogo riska po prezhdevremennomu preryvaniyu beremennosti // Vopr. ginekologii, akusherstva i perinatologii. - 2010. - T. 4, № 9. - S. 28-32.

13. Sidel'nikova V. M., Suhih G. T. Nevynashivanie beremennosti: Rukovodstvo dlya praktikuyushchih vrachej. - M.: OOO «Medicinskoe informacionnoe agentstvo», 2010. - $536 \mathrm{~s}$

14. Strizhakov A. N., Budanov P. V., Davydov A. I. Infekcii, peredavaemye polovym putyom // Klinicheskie lekcii po akusherstvu i ginekologii. - V 2 t. - T. 2. Ginekologiya: Ucheb. posobie / Pod red. A. N. Strizhakova, A. I. Davydova. - M.: OAO «Medicina», 2010. - S. 155-197.

15. Cuhih G. T., Van'ko L. V. Immunnye faktory v ehtiologii i patogeneze oslozhnenij beremen- 
беременности // Акушерство и гинекология. - 2012. - № 1. - С. 128-136.

16. Тирская Ю. И., Белкова Т. Н., Шамина И. В. Оценка цитокиновой регуляции в алгоритме диагностики внутриутробных инфекций у новорождённых от матерей группы высокого риска // Цитокины и воспаление. - 2014. - Т. 13, № 1. - С. 47-50.

17. Хамадьянов У. Р., Русакова Л. А., Хамадьянова А. У. и др. Внутриутробное инфицирование плода: современный взгляд на проблему // Рос. вестн. акушерагинеколога. - 2013. - № 5. - С. 16-20.

18. Чистякова Г. Н., Газиева И. А., Ремизова И. И. и др. Оценка цитокинового профиля при физиологической и патологически протекающей беременности // Цитокины и воспаление. - 2007. - Т. 6, № 1. - С. 3-8. nosti // Akusherstvo i ginekologiya. 2012. - № 1. - S. 128-136.

16. Tirskaya Yu. I., Belkova T. N., SHamina I. V. Ocenka citokinovoj regulyacii v algoritme diagnostiki vnutriutrobnyh infekcij u novorozhdyonnyh ot materej gruppy vysokogo riska // Citokiny i vospalenie. - 2014. T. 13, № 1. - S. 47-50.

17. Hamad'yanov U. R., Rusakova L. A., Hamad'yanova A. U. i dr. Vnutriutrobnoe inficirovanie ploda: sovremennyj vzglyad na problemu // Ros. vestn. akushera-ginekologa. - 2013. - № 5. - S. 16-20.

18. Chistyakova G. N., Gazieva I. A., Remizova I. I. i dr. Ocenka citokinovogo profilya pri fiziologicheskoj i patologicheski protekayushchej beremennosti // Citokiny i vospalenie. -2007 . - T. 6, № 1. - S. 3-8.

19. Castro-Leyva V., Espejel-Nunez A., Barroso G. et al. Preserved ex vivo inflammatory status in decidual cells from women with preterm labor and subclinical intrauterine infection // PLoS One. - 2012. - Vol. 7, N 8. - P. e4360.

20. Mobini M., Mortazavi M., Nadi S. et al. Significant roles played by interleukin-10 in outcome of pregnancy // Iran J. Basic. Med. Sci. - 2016. - Vol. 19, N 2. - P. 119-124.

21. Mor G., Cardenas I. The immune system in pregnancy: a unique complexity // Am. J. Reprod. Immunol. - 2010. - Vol. 63, N 6. - P. 425-433.

22. Racicot K., Kwon J. Y., Aldo P. et al. Understanding the complexity of the immune system during pregnance // Am. J. Reprod. Immunol. - 2014. - Vol. 72, N 2. - P. 107-116.

23. Thaxton J. E., Sharma S. Interleukin-10: A Multi-Faceted Agent of Pregnancy // Am. J. Reprod. Immunol. - 2010. - Vol. 63, N 6. - P. 482-491.

24. Zhan C. Y., Yuan T. M., Sun Y., Yu H. M. Early gestational intrauterine infectioninduces postnatal lung inflammation and arrests lung development in a rat model // J. Matern. Fetal. Neonatal. Med. - 2011. - Vol. 24, N 2. - P. 213-222.

\section{ІМУНОЛОГІЧНІ ПРЕДИКТОРИ ВНУТРІШНЬОУТРОБНОГО ІНФІКУВАННЯ ПЛОДА Й НОВОНАРОДЖЕНОГО ПРИ ВАГІТНОСТІ, УСКЛАДНЕНІЙ БАКТЕРІАЛЬНО-ВІРУСНОЮ ІНФЕКЩЕЮ}

\section{М. О. Щербина, Л. А. Вигівська (Харків)}

Вивчено стан імунної системи у вагітних з урогенітальною інфекцією бактеріальновірусного генезу з метою встановлення критеріїв реалізації внутрішньоутробного інфікування (ВУІ) плода й новонародженого. Проведено порівняльне дослідження стану окремих показників імунної системи 150 вагітних з урогенітальними інфекціями змішаного бактеріальновірусного генезу, які входили до групи ризику розвитку ВУІ плода в II-III триместрах гестаційного періоду. Основну групу становили 68 (45,3 \%) породіль, у дітей яких шляхом клініко-лабораторного обстеження було підтверджено ВУІ. До групи порівняння увійшло 82 (54,7 \%) породіллі з носійством збудників перинатально значущих інфекцій бактеріальновірусного походження, які народили здорових дітей; до контрольної групи - 50 здорових жінок з нормальним перебігом вагітності. Під час дослідження встановлено імунологічні особливості при вагітності, ускладненій ВУІ плода. Оцінювання цитокінової ланки регуляції імунітету дає змогу виявити в групі пацієнток з реалізацією ВУІ достовірне збільшення в II-III триместрах рівня IL-1 $\beta$, IL-6, IL-10, TNF- $\alpha$ з одночасним зниженням вмісту IL-10, більш вираженим у підгрупі жінок, які народили дітей з діагнозом ВУІ, порівняно 3 вагітними, у новонароджених яких не виявлено клінічних проявів хвороби при підтвердженому ВУІ. Реалізація ВУІ при вагітності, ускладненій урогенітальною інфекцією бактеріально-вірусної етіології, на пізніх термінах гестації супроводжується порушенням балансу про- і протизапальних цитокінів з домінуванням перших, показники чого можуть бути використані як предиктори реалізації ВУІ плода.

Ключові слова: внутрішньоутробне інфікування плода, клітинний імунітет, цитокіни. 
ИММУНОЛОГИЧЕСКИЕ ПРЕДИКТОРЫ ВНУТРИУТРОБНОГО ИНФИЦИРОВАНИЯ ПЛОДА И НОВОРОЖДЁННОГО ПРИ БЕРЕМЕННОСТИ, ОТЯГОЩЁННОЙ БАКТЕРИАЛЬНО-ВИРУСНОЙ ИНФЕКЦИЕЙ

\title{
Н. А. Щербина, Л. А. Выговская (Харьков)
}

Изучено состояние иммунной системы у беременных с урогенитальной инфекцией бактериально-вирусного генеза для определения критериев реализации внутриутробного инфицирования (ВУИ) плода и новорождённого. Проведено сравнительное исследование состояния некоторых показателей иммунной системы 150 беременных с урогенитальными инфекциями смешанного бактериально-вирусного генеза, составивших группу риска развития ВУИ плода во II-III триместрах гестационного периода. Основную группу составили 68 (45,3%) рожениц, у детей которых в результате клинико-лабораторного обследования было подтверждено ВУИ; группу сравнения - 82 (54,7 \%) роженицы с носительством возбудителей перинатально значимых инфекций бактериально-вирусной природы, родивших здоровых детей; в контрольную группу - 50 здоровых женщин с нормально протекающей беременностью. В результате исследований установлены иммунологические особенности при беременности, отягощённой ВУИ плода. Оценка цитокинового звена регуляции иммунитета позволила установить в группе беременных с реализацией ВУИ достоверное увеличение во II-III триместрах уровней IL-1 $\beta$, IL-6, IL-10, TNF- $\alpha$ с одновременным снижением уровня IL-10, более выраженное в подгруппе беременных, родивших детей с диагнозом ВУИ, по сравнению с беременными, у новорождённых которых не обнаружены клинические проявления болезни при подтверждённом ВУИ. Реализация ВУИ при беременности, отягощённой урогенитальной инфекцией бактериально-вирусной этиологии, сопровождается на поздних сроках гестации нарушением баланса про- и противовоспалительных цитокинов с доминированием провоспалительных, показатели которых могут быть использованы как предикторы реализации ВУИ плода.

Ключевые слова: внутриутробное инфицирование плода, клеточный иммунитет, цитокины.

\section{ПОКАЗНИКИ МІСЦЕВОГО ІМУНІТЕТУ У ЖІНОК З ПЕРСИСТУЮЧОЮ ФОРМОЮ ЛАТЕНТНОЇ ПАПІЛОМАВІРУСНОЇ ІНФЕКЦІЇ ШИЙКИ МАТКИ ПІСЛЯ ВАКЦИНАЦЇ ПРОТИ ВІРУСУ ПАПІЛОМИ ЛЮДИНИ}

${ }^{1}$ Перинатальний центр Києва; ${ }^{2}$ Кафедра акушерства та гінекології 1 (зав. - проф. Б. М. Венцківський) Національного медичного університету ім. О. О. Богомольця

\begin{abstract}
Проаналізовано зміни показників місцевого імунітету, виявлені через 1 та 6 міс після вакцинацї Цервариксом ${ }^{T M} 35$ жінок з діагностованою персистуючою формою латентної папіломавірусної інфекиії (ПВІ) шийки матки (ШМ). Під впливом вакцинацї вірусом папіломи людини (ВПЛ) через 6 міс у жінок з латентною ПВІ ШМ відмічено тенденцію до нормалізаиіі показників, що характеризують місиевий імунітет, - вмісту в цервікальному відділі sIgA, $\alpha$ - та $\gamma$-ІФН, ФНПдвох останніх показників вказувало на відновлення балансу про- $і$ антизапальних цитокінів). Активізацію гуморального шляху імунної відповіді спостерігали через 1 міс після введення першої дози Цервариксу ${ }^{T м}$ - відмічено підвищення порівняно з контролем медіани для IЛ-10 в 2,5 раза проти 2,2 раза до вакциначії.
\end{abstract}

Ключові слова: папіломавірусна інфекція, шийка матки, місцевий імунітет, вакцинація

Вступ. Нині папіломавірусна інфекція (ПВІ) є актуальною соціально обумовленою проблемою в зв'язку з високою контагіозністю, поширенням та онкогенним потенціалом вірусу папіломи людини (ВПЛ), який визнано етіологічним фактором в генезі рака шийки матки (ШМ) $[1,5]$. Доведено роль ПВІ в розвитку доброякісних і злоякісних новоутворень статевих органів - ВПЛ високого ризику ініціює 